University of Nebraska - Lincoln

DigitalCommons@University of Nebraska - Lincoln

USDA Forest Service / UNL Faculty Publications U.S. Department of Agriculture: Forest Service --

National Agroforestry Center

2010

\title{
Current and future molecular approaches to investigate the white pine blister rust pathosystem
}

\author{
B. A. Richardson \\ USDA Forest Service, brichardson02@fs.fed.us
}

A. K. M. Ekramoddoulah

Canadian Forest Service

J.-J. Liu

Canadian Forest Service

M.-S. Kim

Kookmin University

N. B. Klopfenstein

USDA Forest Service, nklopfenstein@fs.fed.us

Follow this and additional works at: https://digitalcommons.unl.edu/usdafsfacpub

Part of the Forest Sciences Commons

Richardson, B. A.; Ekramoddoulah, A. K. M.; Liu, J.-J.; Kim, M.-S.; and Klopfenstein, N. B., "Current and future molecular approaches to investigate the white pine blister rust pathosystem" (2010). USDA Forest Service / UNL Faculty Publications. 145.

https://digitalcommons.unl.edu/usdafsfacpub/145

This Article is brought to you for free and open access by the U.S. Department of Agriculture: Forest Service -National Agroforestry Center at DigitalCommons@University of Nebraska - Lincoln. It has been accepted for inclusion in USDA Forest Service / UNL Faculty Publications by an authorized administrator of DigitalCommons@University of Nebraska - Lincoln. 
For. Path. 40 (2010) 314-331

doi: 10.1111/j.1439-0329.2010.00660.x

(C) 2010 Blackwell Verlag GmbH and Crown in the right of Canada

\title{
REVIEW
}

\section{Current and future molecular approaches to investigate the white pine blister rust pathosystem}

\author{
By B. A. Richardson ${ }^{1,5}$, A. K. M. Ekramoddoulah ${ }^{2}$, J.-J. Liu' ${ }^{2}$, M.-S. Kim ${ }^{3}$ and \\ N. B. KLOpFEnSTEIN ${ }^{4}$
}

\begin{abstract}
${ }^{1}$ USDA Forest Service, Rocky Mountain Research Station, Provo, UT 84606, USA; ${ }^{2}$ Canadian Forest Service, Pacific Forestry Centre, Victoria, BC V8Z 1M5, Canada; ${ }^{3}$ Kookmin University, College of Forest Sciences, Seoul 134-702, Korea; ${ }^{4}$ USDA Forest Service, Rocky Mountain Research Station, Moscow, ID 59808; ${ }^{5} \mathrm{E}$-mail: brichardson02@fs.fed.us (for correspondence)
\end{abstract}

\begin{abstract}
Summary
Molecular genetics is proving to be especially useful for addressing a wide variety of research and management questions on the white pine blister rust pathosystem. White pine blister rust, caused by Cronartium ribicola, is an ideal model for studying biogeography, genetics, and evolution because: (1) it involves an introduced pathogen; (2) it includes multiple primary and alternate hosts occurring in large, relatively undisturbed ecosystems; (3) some hosts exhibit endemic resistance; and (4) the disease interaction is long enduring. Molecular techniques are used to investigate population genetics, phylogenetics, hybrids, and proteomics in white pine (Pinus, subgenus Strobus) and blister rust (Cronartium) and the genetics of resistance and virulence in the blister rust pathosystem. These techniques include genetic markers, mapping, microarrays, sequencing, association genetics, genomics, and genecology. Molecular genetics contributes to gene conservation, breeding for resistance, and ecosystem management.
\end{abstract}

\section{Introduction}

Molecular genetic tools are proving to be especially useful for a wide variety of research questions in forest pathology (KIM et al. 2005). They have a great potential to quickly provide insights for pathosystems with long-lived individuals, where other experimental approaches would require decades. Various disciplines within genetics (phylogenetics, population genetics, ecological genetics, and functional genomics) use shared molecular tools derived from rapidly developing technologies. Over the last few decades, these technologies have greatly increased the capacity to generate large numbers of highresolution genetic markers (Neale and Ingvarsson 2008). Previous studies were often limited to only a few loci (positions on a chromosome), whereas current genetic analyses routinely assess hundreds to thousands of polymorphic loci. This analytical power continues to increase rapidly, owing to advances in DNA sequencing technologies, highthroughput sequencing, and increased computing power-catalysts for improved capabilities in diverse aspects of molecular genetic research. Numerous techniques can be tailored to meet the research needs for a particular organism and/or hypothesis.

In this review, we focus on technology-driven approaches that have developed within molecular genetics and discuss their ongoing and potential contributions for examining the white pine blister rust pathosystem (Cronartium ribicola J.C. Fisch. in Rabh., pathogen). We review the common molecular techniques presently used in white pine blister rust research and discuss their general utility. We then discuss the rapidly changing disciplines of genomics and proteomics and describe how these can be integrated with other 
disciplines and technologies for application to blister rust research and ecosystem management.

\section{Population genetics}

Population genetics is the study of the organization of genetic variation among individuals within a species (HARTL and CLARK 1997). The evolutionary forces of gene flow, genetic drift, mutation, recombination, and natural selection influence the genetic structure of populations. Each of these evolutionary forces can drive changes in gene frequencies, that is, contribute to differentiation or homogenization of allele (alternative gene forms at the same locus) frequencies among populations (RICHARDSON et al. 2005). Traditional population genetics was confined to investigating neutral, genome-wide effects of gene flow and genetic drift. In contrast, functional genomics now examines locus-specific effects caused by natural selection (VASEMÄGI and PRIMMER 2005) given either prior knowledge of the gene(s) involved in selection or a high number of variable loci to detect selection.

Presently, the most commonly used techniques in population genetics are based on a PCR. These include simple sequence repeats (SSRs or microsatellites), amplified fragment length polymorphisms (AFLPs), and single-nucleotide polymorphisms (SNPs). Each of these techniques has unique qualities and limitations (Glaubitz and Moran 2000). The choice of a marker system depends on the organism and hypothesis. Below, we describe the utility of these genetic markers using examples with white pine (Pinus subgenus Strobus) or C. ribicola (adapted from Kim et al. 2005).

\subsection{Population genetics of white pine species}

Knowledge of genetic diversity and structure of forest tree species or populations is fundamental for genetic resource management (KING et al. 2010). This information is basic for the conservation of genetic diversity critical for long-term adaptability and sustainability of forest tree species (LEDIG 1988; YANCHuk 2001). Data on the organization of genetic diversity fit within a spatial hierarchy from a species-wide distribution to local populations. Different molecular tools are employed to address specific issues and species. For example, RAJORA et al. (2000) used 13 SSR markers to assess the impacts of timber harvest on genetic diversity of eastern white pine (Pinus strobus L.). They showed that harvesting caused stand level losses in unique and rare alleles and reduction in overall allelic richness. But, they left unresolved whether regeneration would perpetuate these losses or whether gene flow from nearby stands would restore lost allelic richness. Kim et al. (2003) used AFLPs to assess genetic diversity in western white pine (Pinus monticola Dougl. ex D. Don) populations within environments of contrasting hazard for C. ribicola. A population grown on a low hazard site had higher heterozygosity and twice as many unique alleles compared with a population grown on a high-hazard site.

Genetic studies of forest trees have provided insights into aspects of gene flow by seed and pollen. Uniparentally inherited, organellar DNA markers have been particularly useful in the Pinaceae. As pines predominately inherit mitochondrial (mt)DNA maternally and chloroplast (cp)DNA paternally (WAGNer 1992; Bruns and Owens 2000), the independent assessments of maternal and paternal gene flows are possible by examining seed or pollen. LAtTA and Mitton (1997) found that mtDNA revealed the strongest differentiation among populations of limber pine (Pinus flexilis James) whereas cpDNA and nuclear markers (RAPDs and allozymes) revealed considerably less differentiation between populations. The differences in allelic frequencies between mtDNA and the other markers were attributed to limited gene flow by seed relative to pollen. This kind of information is useful for identifying interbreeding populations defined by either maternal or paternal gene flow. 
Other studies have used mtDNA markers to investigate seed dispersal distances at various geographical scales for the coevolved whitebark pine (Pinus albicaulis Engelm.) and Clark's nutcracker (Nucifraga columbiana). Whitebark pine regeneration depends on seed caching by Clark's nutcracker (Томваск 2001). Distributions of mtDNA haplotypes suggest that nutcracker caching mixes seeds from different populations, but large gaps $(>20 \mathrm{~km})$ in subalpine habitat pose a significant barrier to seed dispersal by Clark's nutcracker (RICHARDSON et al. 2002b). This information helps restoration programmes by assessing whether natural regeneration would be suitable for specific areas where whitebark pine has been lost (Томваск and Aснuff 2010).

Population genetic structure and diversity, when cross-referenced with paleoecological data, have contributed valuable insights into white pine biogeography. For example, MitTon et al. (2000) proposed eight different glacial refugia for limber pine from RFLP mtDNA data. RichARDson et al. (2002a) used mtDNA and cpDNA patterns in whitebark pine to infer Pleistocene refugia and post-glacial expansions. ECKERT et al. (2008), using a molecular clock on organellar and nuclear DNA sequences, proposed that early- to midglaciation events in the California Sierra Nevada created the disjunct distributions of foxtail pine (Pinus balfouriana Grev. and Balf.). Such studies provide data on past demographic and emigrational changes which aid in understanding how white pines have responded to historical climatic changes and large-scale disturbances and provide relevant information for developing seed-transfer guidelines.

\subsection{Population genetics of Cronartium ribicola}

Population genetic studies of C. ribicola have found varying degrees of genetic structure in North America. The result of a genetic structure study is likely affected by geographic area, detection method, and hypothesis.

Using isozymes, RAPDs, and RFLP markers, KINLOCH et al. (1998) found that genetic diversity and differentiation among populations of C. ribicola in North America were generally low and that genetic distances were not correlated to geographic distance. The largest genetic distance was found between Happy Camp, California, and other populations sampled in western North America. The C. ribicola population at Happy Camp was the only one sampled that possessed the vor1 gene (KInLOCH and Comstock 1981) which defeats the $C r 1 \mathrm{R}$ gene in sugar pine (P. lambertiana Dougl.). Of interest to resistance screening programmes, these techniques suggest that blister rust inoculum sources are broadly similar genetically except for those genes which are strongly selected, such as a virulence gene.

Recent studies have employed AFLPs to investigate the dynamics of population genetic changes in C. ribicola. RichARDSON et al. (2008) found significant differentiation among rust populations associated with rust-resistant plantations and natural stands of either western white pine or sugar pine. The population with the least genetic diversity was sampled from the Happy Camp plantation of sugar pine carrying the $\mathrm{Cr} 1$ gene; the low genetic diversity of this population suggested a genetic bottleneck caused by selection for a virulent rust carrying the $v c r 1$ gene. The sample population with the highest genetic diversity was an Idaho plantation of western white pine selected for multigenic (partial) resistance to blister rust (see KING et al. 2010). This more sensitive technique implies that artificial selection for resistance in white pine is met with rapid natural selection by C. ribicola.

Hamelin et al. (1995) and ET-Touil et al. (1999) used RAPD analyses to examine the population genetic structure of C. ribicola in eastern Canada. They observed that the majority of genetic diversity was found within populations; low-level genetic differentiation occurred among populations within a region, but regional differentiation was not evident among populations of the eastern provinces. The authors proposed this pattern of 
genetic structure in C. ribicola was influenced by a founder effect from the pathogen's recent introduction. Hamelin et al. (2000) subsequently demonstrated that C. ribicola populations in eastern and western North America are distinct. Movement of C. ribicola that bridges eastern and western North America could have greater genetic significance than has been observed within the two epidemics.

McDonald et al. (2006) reported discovery of C. ribicola on Pedicularis racemosa Dougl. ex Benth. and Castilleja miniata Dougl. ex Hook. in Idaho. Ribosomal DNA sequencing [internal transcribed spacer (ITS) and 5.8S] and artificial inoculations of $R$. nigrum L. and western white pine seedlings were used to confirm the determination. AFLP profiles of rust isolates from three telial hosts (Ribes budsonianum Richards., $R$. lacustre (Pers.) Poir., and P. racemosa) and two aecial hosts (western white pine and whitebark pine) from this Idaho site detected no genetic differentiation among rust isolates derived from different hosts. Additional rust isolates from elsewhere in the western or the eastern United States were demonstrated by artificial inoculation capable of infecting $P$. racemosa, a western endemic. Genetic analyses together with artificial inoculations suggest that North American C. ribicola has long possessed a capacity to infect these hosts (RICHARDSON et al. 2007), but the epidemiological consequences of this are unknown.

\section{Hybridization}

Molecular genetic tools have been very effective for the detection of intraspecific and interspecific hybrids in the Pinaceae (Latta and Mitton 1999; Rajora and Dancik 2000). Host hybrid zones are known to affect disease resistance (Wu et al. 1996) and the population genetic structure of a pathogen (JEROME and Ford 2002). Both plant and pathogen hybrids have been discovered in poplar plantations. For example, one poplar hybrid (Populus trichocarpa $\times P$. deltoides) became infected by a leaf rust, Melampsora $\times$ columbiana that arose following hybridization between $M$. occidentalis and M. medusae (Newcombe et al. 2000).

Joly et al. (2006) demonstrated that C. ribicola in stands of limber pine can hybridize with comandra blister rust (C. comandrae Peck) to form aeciospores. Because these spores have not been observed to infect Ribes or other hosts, the pathogenicity and biological implications of this interspecific hybridization, such as the contribution to gene flow, are unknown. Hybridization could be very important for blister rust management if it increased host range or environmental tolerance of the pathogen.

\section{Phylogenetics}

In comparison with population genetics which uses allelic frequencies to quantify relationships among species populations, phylogenetics typically investigates evolutionary relationships among taxa (groups of organisms related at any rank) by reconstructing the history of nucleotide substitutions within a gene family (GRAUR and LI 2000). Genetic loci, like the ITS of the nuclear ribosomal (r)DNA, are often used in phylogenetic studies among sister taxa (Vogler and Bruns 1998; Senters and Soltis 2003). For research on more distant (older) phylogenetic relationships, highly conserved genes, such as the ribosomal large subunit, are examined (MAIER et al. 2003). New DNA sequencing technologies, increased computing power, and mathematical modelling methods could fundamentally change phylogenetics and other disciplines in genetics.

Phylogenetic analyses using mtDNA, cpDNA, and nuclear (n)DNA sequences are proving especially valuable tools for resolving the complex evolutionary histories of the pine taxa infected by C. ribicola. PRICE et al. (1998) presented a classification of the genus Pinus, including the subgenus Strobus with its constituent sections and subsections (see 
Tomback and Achuff 2010; Table 1). According to Price et al. (1998), section Strobus includes subsection Strobi (white pines like P. strobus) and subsection Cembrae (stone pines like whitebark pine); section Parrya includes subsection Balfourianae (foxtail pines), subsection Cembroides (pinyon pines, North America), and subsection Gerardianae (Asian pines of uncertain affinity). Although phylogenic analysis supported Strobi as a monophyletic group (exclusively share a single common ancestor), the placement of Balfourianae as a sister taxon to section Strobus was unresolved (Liston et al. 1999; WANG et al. 1999; WANG et al. 2000; GernANDT et al. 2001). More recent studies concluded that Balfourianae is more closely related to Cembroides than Strobus (GERnAndT et al. 2005; SYRING et al. 2005).

Detailed phylogenetic studies with more sampling within taxa have shown that alleles among taxa of subgenus Strobus are not always monophyletic (SYRING et al. 2007). This non-monophyly can be a result of one or more processes such as introgression, recombination, or incomplete lineage sorting. Taxonomic distinctions such as between limber pine and southwestern white pine may have to yield to a more complex but realistic understanding of biological populations.

Although phylogeny within subgenus Strobus is complex, knowledge of genetic relationships and host ranges of C. ribicola can increase our understanding of the evolution of the white pine blister rust pathosystem. Blister rust infects many species within several distinct taxa, including Strobi, Cembrae, and Balfourianae. Such a broad host range suggests that all species within these taxa would be susceptible but leaves unclear if species within sister taxa such as Gerardianae and Cembroides would also be susceptible.

Phylogenetic approaches are used to assess evolutionary relationships within the Cronartium. Vogler and Bruns (1998) used ITS rDNA sequences to study the phylogenetic relationships of 24 Eurasian and North American pine stem rusts. They found that closely related rust species (as determined by molecular phylogenetics) generally shared a common plant family for their telial hosts, implying that switches to different telial host families are important for speciation for pine stem rusts. The exceptional case involves C. ribicola and C. occidentale, species that share a common telial genus-Ribes (although C. ribicola alternates to Strobi, Cembrae, and Balfourianae and C. occidentale alternates to Cembroides). These two stem rusts are more phylogenetically distant from each other than are several other species with different telial host species. Although C. occidentale might be taken as a native stem rust model for a naturalized C. ribicola as they are both pathogens of Ribes and Strobus, other Cronartium pathosystems could also be informative.

Ongoing work seeks to elucidate the phylogeographic relationships between C. ribicola in North America and Eurasia (RichARDSON et al. 2009) and to gain insight to the origin(s) of the rust that spread throughout Europe and subsequently to North America (see GeILs et al. 2010). RichaRDSON et al. (2009) found at least two distinct phylogenetic groups in Asia-one in Japan and the other in South Korea-northeastern China (see Kıм et al. 2010; ZHANG et al. 2010). These Asian groups were also distinct from rust collected in western Europe or North America (Fig. 1). The North American white pine blister rust introduced from Europe represents only a fraction of the genetic diversity of C. ribicola; its greater potential might be unexpressed but able to emerge as a result of climatic changes or introduction of an Asian blister rust.

Studies have also addressed the phylogenetics of telial hosts-Ribes species (SENTERs and Soltis 2003; Schultheis and Donoghue 2004) and Pedicularis species (Ree 2005). Characterization of white pine blister rust resistance in Ribes and Pedicularis in light of this phylogenetic data should help our understanding of the evolution of resistance (see Zambino 2010).

A molecular clock is a means to estimate species divergence dates. The premise of a molecular clock is that the number of nucleotide substitutions (mutations) between gene 


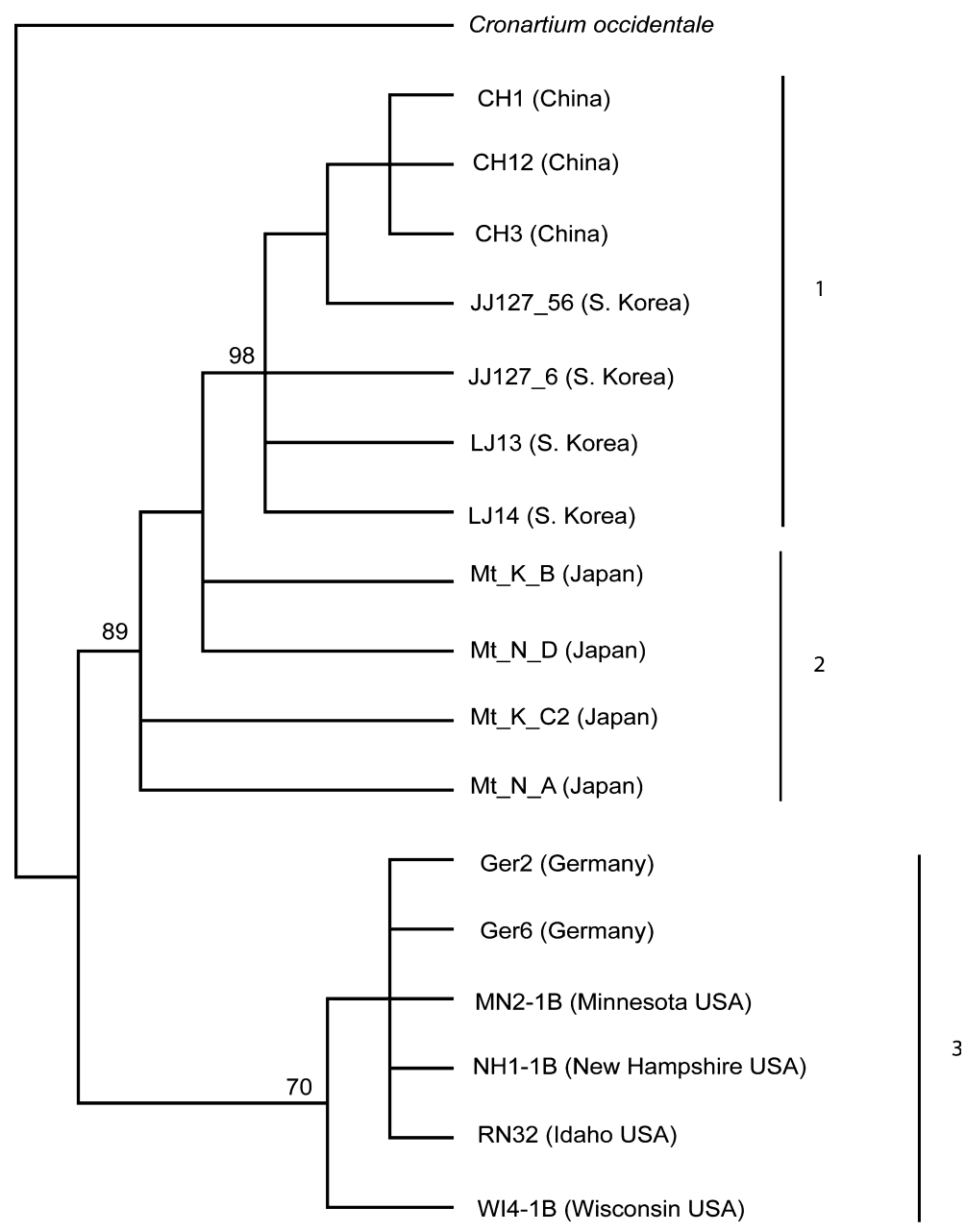

Fig. 1. The phylogenetic relationships of Cronartium ribicola isolates developed from maximum likelihood analysis. Three distinct clades are represented and supported by high-bootstrap support. These clades represent three distinct geographic regions: (1) eastern Asia (Korea and northeastern China), (2) Japan, and (3) North America and western Europe (adapted from Richardson et al. 2009).

sequences of species increases with time since divergence. This assumes that mutations occur at a relatively constant rate over time. A molecular clock is calibrated by fossil evidence or the timing of biogeographical events such as the separation of continents or climatic change. As mutation models for particular gene sequences improve, so should the accuracy of divergence estimates (reviewed in ARBogast et al. 2002). However, the inaccurate estimations of divergence times and potential fluctuation in mutation rates challenge an apparent precision of molecular clocks; thus, molecular clock data warrant cautious interpretations (GRAUR and MARTIN 2004). Presently, molecular clocks have been used to date the divergence of genera in the Pinaceae (WANG et al. 2000; WILlyard et al. 2007) but not for divergence times in the Cronartium. 


\section{Proteomics}

Proteomics is the study of proteins expressed by a genome interacting inside an organism, tissue, or cell at a specific developmental stage or in response to an external or internal stimulus. Profiles including several thousands of proteins are typically generated using two-dimensional gel electrophoresis for separation of proteins by charge and size. Separated protein spots are then cut from a gel and digested with trypsin; and the resulting peptides are characterized by mass spectrophotometric techniques such as matrix-assisted laser densitometry ionization tandem-mass spectrophotometer (MALDI-MS). Cataloguing is accomplished by database searching for probable matches using either peptide mass or more expensive peptide sequences. Identifying and resolving the mode of action for the proteins coded by resistance or virulence genes provides us with a better understanding of the genetics and physiology of white pine blister rust that could be useful for developing new screening and breeding approaches.

DAVIDSON and EKRAMODDOULLAH (1997) detected $>800$ proteins in white pine seedlings and quantified 146 as expressed differentially between white pine seedlings either susceptible or resistant to C. ribicola. Further investigations have revealed there are many defence-responsive proteins involved in blister rust resistance (LiU et al. 2004). Proteome profiling of $>1200$ proteins from spruce attacked or not by weevils found that 104 were differentially expressed; $72 \%$ were identified by LC-MS/MS analysis and database searching (LIPPERT et al. 2007).

EKRAMODDOULlaH (2004) reviewed an additional strategy for detecting and characterizing proteins related to host defence. This technique used either a synthetic peptide identified from a proteomic study or a known DNA coding sequence to make a corresponding antibody that attaches to a protein with the peptide of interest. Such proteomic studies of western white pine infected with C. ribicola have led to discoveries of defence-response proteins belonging to the pathogenesis-related (PR) protein groups PR3, PR5, and PR10 and to an anti-fungal peptide (EKRAmodDoullaH 2004).

White pine PR10 was identified as one of 19 plant PR families. Differential response to biotic and abiotic stimuli among protein members of this gene family indicated that different members of this gene family have evolved to assume diverse functions (LIU and Ekramoddoullah 2003b). Gene promoter analysis of two PR10 genes revealed characteristics of cis-regulatory elements (nearby DNA sequences that promote or silence expression) including a fungal elicitor and cold-responsive elements (LiU and EKRAMODDOULLAH 2003a; LiU et al. 2005b). Hunt (2005) showed that western white pine stock resistant to blister rust at cooler, high-elevation sites was susceptible at warmer lowelevation sites; the resistance response could have been induced by PR10 proteins stimulated by exposure to low temperature.

Proteomics is useful for identifying DNA markers associated with genes involved in specific resistance mechanisms. A large-scale screening programme at the Canadian Forest Service found two partial-resistance mechanisms in western white pine-a slow-cankergrowth trait and a difficult-to-infect trait (LiU et al. 2004; KING et al. 2010). Two proteins, an anti-microbial peptide (PmAMP1) and one isoform of class IV chitinase, were associated with the slow-canker-growth trait (Ekramoddoullah 2004). The peptide PmAMP1 is degraded by C. ribicola as infection advances in cankered, susceptible western white pine; whereas the levels of this protein are unaffected in trees with the slow-cankergrowth trait and a receding canker margin (EKRAMODDOULlaH et al. 2006). The regulation of PmAMP1 is presently the subject of intensive research by the Canadian Forest Service as it might provide a key for development of a DNA-based marker to screen western white pine for the slow-canker-growth trait.

After infection by C. ribicola, the isoform of $27-\mathrm{kDa}$ class IV chitinase from western white pine PR3 family accumulated in both susceptible seedlings and those with the 
slow-canker-growth trait, whereas a different $26-\mathrm{kDa}$ PR3 isozyme was expressed specifically in seedlings with the slow-canker-growth trait (LiU et al. 2005a). The difference between seedlings with the slow-canker-growth trait and susceptible seedlings was not only measurable at the chitinase protein level but also at the genomic DNA level. Re-sequencing of chitinase genes revealed a genetic difference between susceptible families and those with the slow-canker-growth trait. The introns of class IV chitinase genes showed a SNP and multiple intron-length polymorphisms. Future work on class IV chitinases in western white pine could provide another tool for marker-assisted selection in white pine breeding and determine whether class IV chitinases are involved as a general defence factor in the slow-canker-growth mechanism.

\section{Genetics of resistance and virulence}

Molecular characterization of the genes and proteins involved in resistance and virulence is critical for understanding the function, evolution, and stability of the white pine blister rust pathosystem and therefore for designing effective management strategies. One of the most well-studied and understood resistance-virulence systems is the hypersensitive reaction (HR) that conforms with the gene-for-gene concept of FLOR (1971). The genes involved in the HR response and the encoded proteins from both host and pathogen have been characterized in several model pathosystems. The HR response is triggered by interaction of a plant receptor (presumably coded by an $\mathrm{R}$ gene) with a pathogen elicitor. The result of this resistance reaction is an activation of signal cascades that lead to programmed cell death of infected and adjacent cells. The process is typically initiated by a single, dominant, $\mathrm{R}$ gene that encodes a cytoplasmic or membrane-bound receptor (reviewed in HAMmONDKosack and Jones 1997; Gilchrist 1998; Ekramoddoullah and Hunt 2002). In the plant systems studied thus far, the $\mathrm{R}$ genes controlling an $\mathrm{HR}$ response have a sequence homology across diverse plant taxa (MEYERs et al. 1999; Meyers et al. 2002). Because these resistance genes are conserved among plant taxa, readily available PCR primers can be used to characterize these genes in white pine families.

Several white pine families appear to express an HR phenotype coded by an $\mathrm{R}$ gene (KING et al. 2010). Determining the molecular characteristics of such $\mathrm{R}$ genes is a daunting task owing to the large size of a conifer genome (WAKAmIYA et al. 1993). One method uses PCR-based amplification of candidate R genes (KIM and BRUNSFELD 2000; LIU and Ekramoddoullah 2003a). Liu and Ekramoddoullah (2003a) used this approach to selectively amplify PCR products and create a clonal library from western white pine families carrying $\mathrm{Cr} 2$, the $\mathrm{R}$ gene associated with $\mathrm{HR}$ in western white pine. JERMSTAD et al. (2006) completed similar work for sugar pine. $\mathrm{R}$ genes are potentially under evolutionary pressure as novel virulence gene products are produced.

A resistance gene analogue (RGA) is a genetic loci that putatively translates a resistanceprotein motif. The cloned nucleotide-binding (NB) sequences of western white pine RGAs correspond to two subfamilies of $\mathrm{R}$ genes-toll and interleukin-1 (TIR)-NB-leucine-rich repeat (LRR) (LiU and Ekramoddoullah 2003a) and coiled-coil (CC)-NB-LRR (LiU and EKRAmodDoullah 2007). The observed high degree of variation in these western white pine NB domains suggests that it contributes to genetic fitness in conifers. By precise domain swapping, various studies have shown that the numbers of LRRs are critical determinants of interactions with avirulence elicitors (VAN DER VOSSEN et al. 2000; XIAO et al. 2001). One RGA found in western white pine has almost identical TIR and NB domains but variable LRR lengths (EKRAMODDOULLAH and LIU 2008). These LRR regions are rich in DNA polymorphisms and could be used to develop DNA markers for the saturated genetic mapping of the $\mathrm{Cr} 2$ gene (LiU and EKramodDoullaH 2008).

The generation of novel resistance mechanisms by somatic mutation or recombination would be particularly advantageous for conifer species which are composed of individual 
trees that live for hundreds to thousands of years (Michelmore and Meyers 1998). Ontogenetic resistance increases with plant development or age and has been observed in several white pine species (PAtTon 1961; Kinloch and Byler 1981; Hunt 2004a). Comparison of R-protein structures that determine pathogen specificity could provide useful information on the mechanisms by which ontogenetic resistance operates.

Elicitors usually are proteins excreted by pathogens, such as the protein Cro rI excreted by C. ribicola (Yu et al. 2002). This protein has only been detected in the haploid stage during mycelial growth either in the pine host or in vitro. As the Cro rI is only present in symptomatic infections, Yu et al. (2002) postulated the protein is involved with pathogenicity. The Cro rI protein might function as a virulence factor and elicitor of $\mathrm{HR}$ in the $\mathrm{Cr} 2$ resistance. When extracts containing Cro $\mathrm{rI}$ are introduced by injection into western white pine carrying the $\mathrm{Cr} 2$ gene, an $\mathrm{HR}$ response is induced that mimics resistance to the intact pathogen (Ekramoddoullah, unpublished data). The Cro rI protein would have to be further purified to determine its mode of action as either an elicitor or virulence factor. A population genetic study of SNPs of the cro $r \mathrm{I}$ gene might be able to explain the role of the Cro rI protein in the white pine blister rust pathosystem. A single amino acid sequence difference could allow the virulence protein to avoid recognition by the host. SCHÜRCH et al. (2004) suggested that deletion or alteration of an avirulence gene might allow a fungal pathogen to avoid recognition by the corresponding resistance gene of the host.

\section{Future and ongoing approaches}

The white pine blister rust pathosystem has several characteristics useful for clarifying evolution of the invasive pathogen, C. ribicola. First, the epidemiological interactions of blister rust often occur in natural ecosystems, providing an in vivo experiment from local to continental spatial scales across diverse landscapes and in different communities. Second, resistance to an exotic pathogen is seldom found in native forest pathosystems (e.g., chestnut blight, Dutch elm disease); but such inherited resistance occurs in most white pine species. Third, plant-pathogen interactions of decades or longer have rarely been investigated. The history of blister rust investigations provides researchers with long-term data on ecology and evolutionary biology.

In this section, we discuss new approaches and tools that could aid in the dissection of the blister rust plant-pathogen interactions and evolution. This knowledge is critical for making science-based management decisions that might favour stabilization of disease epidemics and encourage pathosystem naturalization.

\subsection{Molecular plant-pathogen interactions}

Genomic and proteomic approaches using cDNA libraries are emerging that link the molecular and phenotypic bases of plant defences and pathogen infection. A cDNA library is a collection of individual DNA sequences derived by reverse transcription from messenger (m)RNA of expressed genes in pathogen-challenged and unchallenged hosts. The expressed genes or expressed sequence tags (ESTs) are sequenced, and hybridization experiments reveal the upregulation or downregulation of genes (increase or decrease in gene expression owing to change in sensitivity or number of receptors). Our understanding of the molecular basis of plant-pathogen interactions in white pine blister rust should improve as more genes are discovered in the various resistance and virulence pathways and associated with proteins of known function. In a practical sense, this means being able to describe at a molecular level how plant genes code for proteins that provide a defence and how rust genes defeat it. 
A microarray consists of thousands of single-stranded cDNAs fixed onto a glass slide, called a DNA chip. Gene expression is quantified by hybridizing control and experimental samples and assessing relative fluorescence of target gene sequences (reviewed in Gibson 2002; BRYANT et al. 2004). A microarray approach allows tens of thousands of genes to be examined in a single pass for changes in regulation. The approach has diverse applications at individual, population, and species levels (Whitehead and Crawford 2006). For example, RALPH et al. (2006) studied genetic interactions resulting from herbivory of hybrid poplars by forest tent caterpillars. Sequence technology, however, could soon replace microarrays as sequencing can now be conducted simultaneously on a whole cDNA library and provide information unavailable from microarrays.

Gene expression has been studied in several pathosystems. In the blister rust pathosystem, a large number of proteins were differentially regulated following C. ribicola challenge of western white pine (Ekramoddoullah and Hunt 1993; Ekramoddoullah and TAN 1998). Differential gene expression was examined for fusiform rust [Cronartium quercuum (Berk.) Miyabe ex Shirai f. sp. (fusiforme) on slash pine (P. elliottii) Engelm.] by comparing RNA extracted from host gall tissue to RNA from healthy tissue and axenic rust cultures (WARREN and COVERT 2004). In another study, gene expression was assessed from the interaction of slash pine with Gibberella circinata Nirenberg and O'Donnell, causal agent of pitch canker. Pine genes upregulated or downregulated in the fusiform rust pathosystem differed considerably from those in the pitch canker pathosystem. These differences were expected, as there are fundamental phytopathological differences between biotrophic Cronartium fungi and necrotrophic Gibberella fungi (MORSE et al. 2004).

New strategies of molecular characterization of white pine R genes $(\mathrm{Cr} 1, \mathrm{Cr} 2$, and $\mathrm{Cr} 3$ ) could be developed. A biochemical model for the gene-for-gene interaction predicts that an avirulence-gene product (presumably an HR elicitor) would directly or indirectly interact with an R-gene product to trigger the signal transduction pathway leading to activation of defence-related genes. Acting in concert, these gene products give rise to the HR response.

Bendahmane et al. (2000) described a method to establish the functionality of RGAs. Test plants are transformed with an avirulence gene and then infiltrated with transiently expressed RGA cDNA using Agrobacterium-based methods. A plant exhibiting HR is taken as evidence the RGA is an R gene interacting with an avirulence gene. If avirulence gene(s) of C. ribicola could be identified and cloned, then this approach could identify $\mathrm{R}$ genes among white pine RGAs.

A yeast two-hybrid analysis screens for interacting proteins using a 'bait and fish' strategy (Lodish et al. 2004). For example, a 'bait' is a protein of interest such as the Cro rI protein produced by C. ribicola and the 'fish' are proteins from a white pine cDNA library. The method requires fusing proteins to binding and activation domains, constructing plasmids with selectable markers, transforming the plasmids into yeast cells, growing and plating the yeast on selective media, and sequencing the DNA of plasmids isolated from the selected cells. The process screens for those white pine proteins that bind to the Cro rI protein, thereby identifying which host proteins interact with a pathogen protein of known or putative function. Alternatively, a protein produced by a host could be used to screen for interacting pathogen proteins.

\subsection{Genetic mapping and association genetics}

Traditional genetic mapping employs genetic markers such as AFLPs, SNPs, and microsatellite markers to associate qualitative and quantitative traits through segregation of alleles and traits. Traits tightly linked to markers can be used for cloning a region containing a gene of interest or for marker-assisted selection (reviewed in MACKAY 2001). Cloning from linked markers works well for organisms with relatively small genomes, mutant lines, or transformation approaches. 
Several studies have mapped traits of interest among the Pinaceae. Maps have been developed for qualitative traits such as R-gene resistance to C. ribicola in sugar pine, $\mathrm{Cr} 1$ (Devey et al. 1995; Harkins et al. 1998) and in western white pine, Cr2 (Liu and Ekramoddoullah 2006). Maps are also developed for quantitative traits such as wood properties (BROWN et al. 2003) and timing of bud break or bud set (JERMSTAD et al. 2003). The utility of comparative maps has also been demonstrated with loblolly pine ( $P$. taeda L.), Douglas-fir [Psendotsuga menziesii (Mirb.) Franco], and other Pinaceae (Krutovsky et al. 2004). Mapping of resistance traits in white pines and virulence in C. ribicola should be simplified as additional molecular markers and newer, high-throughput sequencing technologies become available (ЕсHT et al. 1999; Kim et al. 2003; RicHARDSON et al. 2008).

An alternative to traditional mapping is association genetics which was developed for human disease research (GOLDSTEIN and WEALE 2001) but is especially practical for the conifers which characteristically have large genomes and long generations times. Association genetics relies upon life-history characteristics (for conifers, random mating with high-gene flow) and the use of numerous candidate genes to determine associations with phenotypes (Neale and Savolainen 2004; González-Martínez et al. 2006; Neale and IngVarsson 2008). Given that resistant phenotypes and quantitative traits are well characterized in several white pine species, association genetics should be readily applicable to the white pine blister rust pathosystem.

\subsection{Population genomics and genecology}

Population genomics is the study of genome-wide patterns of genotypes for addressing natural selection and demographic processes. Approaches in population genomics vary from analyses of specific adaptive traits (such as association genetics) to elucidating genetic patterns to order to make inferences of demographic history and identify putative targets of selection. This later approach is known as a genome scan (VAsemägi and Primmer 2005; BISWAS and AKEY 2006). Genome scans have been performed over a wide range of organisms such as humans, fish, and oak (Akey et al. 2002; CAmpbell and Bernatchez 2004; ScotTi-Saintagne et al. 2004). Implementing hundreds of molecular markers to saturate the genome, researchers have the capability to detect putative loci under positive selection based on the overall level of genetic differentiation among loci. Statistics test whether loci have genetic differentiation that is greater than expected under neutrality and therefore suggests operation of genetic drift, mating, or gene flow.

Genecology, the study of associating genetic responses to environment, has been traditionally addressed with the use of quantitative traits. Such studies have provided important information regarding climatic adaptation of white pines (REHFELDT et al. 1984; Bower and Aitken 2008) and other conifer species. More recently, the use of climate models (Hijmans et al. 2005; RehFeldt 2006) has enabled researchers to discern associations between quantitative traits and climatic variables mapped at high-spatial resolution, providing climate-based genecological models (REHFELDT et al. 2001; ST CLAIR et al. 2005). Given the volume of molecular data that can be generated, such genecolgical approaches could be used to identify putative selective signatures; and comparisons could be drawn between adaptive traits and molecular markers.

As the knowledge of genes and their functions increase in white pine, blister rust, and related pathosystems, the abilities to link genes to processes of disease, evolution, and ecological adaptation should improve. Currently, efforts are underway to create a knowledge base in the white pine blister rust pathosystem to address these questions. For example, the American Phytopathological Society (2003) has listed C. ribicola as a high-priority organism for DNA sequencing, and plans are ongoing to develop an EST library (R. Hamelin, personal communication). Genomic sequencing of white pines is a daunting task owing to the large genome size. However, comparative genomics could help 
elucidate a molecular basis of resistance mechanisms and thereby suggest how to improve resistance for natural or artificial regeneration of white pine.

\section{Conclusion}

The white pine blister rust pathosystem presents unique opportunities to research fundamental questions in biology and to support management for healthy ecosystems. Phylogeny and population genetics reveal clues to the biogeography and evolution of Strobus and Cronartium -ideas useful for genetic conservation and management. Genetics and proteomics generate information on the inheritance and expression of resistance and virulence-practical data for regenerating white pines. Studies of invasive ecology and co-evolution enhance our understanding of host and pathogen interactions-knowledge valuable to sustain resilient populations. Molecular techniques provide the keys to addressing these questions.

\section{Acknowledgements}

This article was supported by the USDA Forest Service, RMRS, Forest and Woodland Ecosystems. The authors thank Dennis E. Ferguson, Tobin L. Peever, Marcus V. Warwell, Paul J. Zambino and two anonymous reviewers for their thoughtful reviews.

\section{References}

AkeY, J.M.; Zhang, G.; Zhang, K.; Jin, L.; Shriver, M.D., 2002: Interrogating a high-density SNP map for signatures of natural selection. Genome Res. 12, 1805-1814. [Online]. doi: 10.1101/ gr.631202

American Phytopathological Society, 2003: Microbial Genomic Sequencing: Perspectives of the American Phytopathological Society. St. Paul, MN: American Phytopathological Society. 21 p. [Online]. Available: http://www.apsnet.org/media/ps/MicrobialGenomicsSeqFinal03.pdf

Arbogast, B.S.; Edwards, S.V.; Wakeley, J.; Beerli, P.; Slowinski, J.B., 2002: Estimating divergence times from molecular data on phylogenetic and population genetic timescales. Annu. Rev. Ecol. Syst. 33, 707-740. [Online]. doi: 10.1146/annurev.ecolsys.33.010802.150500

Bendahmane, A.; Querci, M.; Kanyuka, K.; Baulcombe, D.C., 2000: Agrobacterium transient expression system as a tool for the isolation of disease resistance genes: Application to the Rx2 locus in potato. Plant J. 21, 73-81. [Online]. doi: 10.1046/j.1365-313x.2000.00654.x

Biswas, S.; Akey, J.M., 2006: Genomic insights into positive selection. Trends Genet. 22, 437-446. [Online]. doi: 10.1016/j.tig.2006.06.005

Bower, A.D.; AitKen, S.N., 2008: Ecological genetics and seed transfer guidelines for Pinus albicaulis (Pinaceae). Am. J. Bot. 95, 66-76. [Online]. Available: http://www.amjbot.org/cgi/content/ abstract $/ 95 / 1 / 66$

Brown, G.R.; Bassoni, D.L.; Gill, G.P.; Fontana, J.R.; Wheeler, N.C.; Megraw, R.A.; Davis, M.F.; Sewell, M.M.; Tuskan, G.A.; Neale, D.B., 2003: Identification of quantitative trait loci influencing wood property traits in loblolly pine (Pinus taeda L.). I. Genetics 164, 1537-1546. [Online]. Available: http://www.genetics.org/cgi/content/abstract/164/4/1537

Bruns, D.; Owens, J.N., 2000: Western white pine (Pinus monticola Dougl.) reproduction: II. Fertilization and cytoplasmic inheritance. Sex. Plant Reprod. 13, 74-84. [Online]. doi: 10.1007/ s004970000041

Bryant, P.A.; Venter, D.; Robins-Browne, R.; Curtis, N., 2004: Chips with everything: DNA microarrays in infectious diseases. Lancet Infectious Diseases 4, 100-111. [Online]. doi: 10.1016/ S1473-3099(04)00930-2

Campbell, D.; Bernatchez, L., 2004: Genomic scan using AFLP marker as a means to assess the role of directional selection in the divergence of sympatric whitefish ecotypes. Mol. Biol. Evol. 21, 945956. [Online]. doi: 10.1093/molbev/msh101

Davidson, J.; EKramoddoullah, A.K.M., 1997: Analysis of bark proteins in blister rust-resistant and susceptible western white pine (Pinus monticola). Tree Physiology 17, 663-669. [Online]. Available: http://heronpublishing.com/tree/pdf/volume17/17-663.pdf 
Devey, M.E.; Delfino-Mix, A.; Kinloch, B.B., Jr; Neale, D.B., 1995: Random amplified polymorphic DNA markers tightly linked to a gene for resistance to white pine blister rust in sugar pine. PNAS 92, 2066-2070. [Online]. doi: 10.1073/pnas.92.6.2066

Echt, C.S.; Vendramin, G.G.; Nelson, C.D.; Marquardt, P., 1999: Microsatellite DNA as shared genetic markers among conifer species. Canadian Journal of Forest Research 29, 365-371. [Online]. doi: 10.1139/cjfr-29-3-365

Eckert, A.J.; Tearse, B.R.; Hall, B.D., 2008: A phylogeographical analysis of the range disjunction for foxtail pine (Pinus balfouriana, Pinaceae): the role of Pleistocene glaciation. Mol. Ecol. 17, 1983-1997. [Online]. doi: 10.1111/j.1365-294X.2008.03722.x

Ekramoddoullah, A.K.M., 2004: Current strategies for studying proteins in forest tree-pathogen interaction. Recent Research in Development, Biotechnology, and Bioengineering 6, 51-63.

Eкramoddoullah, A.K.M.; Hunt, R.S., 1993: Changes in protein profile of susceptible and resistant sugar pine foliage infected with the white pine blister rust fungus Cronartium ribicola. Canadian Journal of Plant Pathology 15, 259-264. [Online]. Available: http://www.cps-scp.ca/cjpp/ cjpp1993.html

Eкramoddoullah, A.K.M.; Hunt, R.S., 2002: Challenges and opportunity in studies of hostpathogen interactions in forest tree species. Canadian Journal of Plant Pathology 24, 408-415. [Online]. Available: http://warehouse.pfc.forestry.ca/pfc/.pdf

Ekramoddoullah, A.K.M.; Liu, J.-J., 2008: Genomic cloning and promoter analysis of Pinus monticola resistance gene analog (PmRGA) of the NBS-LRR family. In: Annual meeting of the Canadian Phytopathological Society, Charlottetown, PE, 2008 June 15-19.

Ekramoddoullah, A.K.M.; Tan, Y., 1998: Differential accumulation of proteins in resistant and susceptible sugar pine inoculated with blister rust fungus, Cronartium ribicola. Canadian Journal of Plant Pathology 20, 308-318. [Online]. Available: http://www.cps-scp.ca/download/cjpp-archive/ Vol20/CJPP20(3)308-318(1998).pdf

Ekramoddoullah, A.K.M.; Liv, J.J.; Zamani, A., 2006: Cloning and characterization of a putative antifungal peptide gene (Pm-AMP1) in Pinus monticola Douglas ex D. Don. Phytopathology 96, 164-170. [Online]. doi: 10.1094/PHYTO-96-0164

ET-Touil, K.; Bernier, L.; Beaulieu, J.; Bérubé, J.A.; Hopkin, A.A.; Hamelin, R.C., 1999: Genetic structure of Cronartium ribicola populations in eastern Canada. Phytopathology 89, 915-919. [Online]. doi: 10.1094/PHYTO.1999.89.10.915

FLOR, H.H., 1971: Current status of the gene-for-gene concept. Annual Review of Phytopathology 9, 275-296. [Online]. doi: 10.1146/annurev.py.09.090171.001423

Geils, B.W.; Hummer, K.E.; Hunt, R.S., 2010: White pines, Ribes, and blister rust: a review and synthesis. For. Pathol. 40, 147-185.

Gernandt, D.S.; Liston, A.; Piñero, D., 2001: Variation in the nrDNA ITS of Pinus subsection Cembroides: Implications for molecular systematic studies of pine species. Mol. Phylogenet. Evol. 21, 449-467. [Online]. doi: 10.1006/mpev.2001.1026

Gernandt, D.S.; López, G.G.; García, O. S.; Liston, A., 2005: Phylogeny and classification of Pinus. Taxon 54, 29-42. [Online]. Available: http://www.jstor.org/stable/25065300

Gibson, G., 2002: Microarrays in ecology and evolution: a preview. Mol. Ecol. 11, 17-24. [Online]. doi: 10.1046/j.0962-1083.2001.01425.x

Gilchrist, D.G., 1998: Programmed cell death in plant disease: The purpose and promise of cellular suicide. Annual Review of Phytopathology 36, 393-414. [Online]. doi: 10.1146/annurev. phyto.36.1.393

Glaubitz, J.C.; Moran, G., 2000: Genetic tools: The use of biochemical and molecular markers. In: Forest conservation genetics. Ed. By Young, A.; Boshier, D.; Boyle, T. Oxon, UK: CABI Publishing. pp. 39-59.

Goldstein, D.B.; Weale, M.E., 2001: Population genomics: Linkage disequilibrium holds the key. Curr. Biol. 11, R576-R579. [Online]. doi: 10.1016/S0960-9822(01)00348-7

González-Martínez, S.C.; Krutosky, K.V.; Neale, D.B., 2006: Forest-tree population genomics and adaptive evolution. New Phytol. 170, 227-238. [Online]. doi: 10.1111/j.1469-8137. 2006.01686.x

Gould, S.J., 2002: The Structure of Evolutionary Theory. Cambridge, MA: Harvard University Press. $1433 \mathrm{p}$.

Graur, D.; LI, W.-H., 2000: Fundamentals of Molecular Evolution. Sunderland, MA: Sinauers Associates.

Graur, D.; Martin, W., 2004: Reading the entrails of chickens: Molecular timescales of evolution and the illusion of precision. Trends Genet. 20, 80-86. [Online]. doi: 10.1016/j.tig.2003.12.003 
Hamelin, R.C.; Beaulieu, J.; Plourde, A., 1995: Genetic diversity in populations of Cronartium ribicola in plantations and natural stands of Pinus strobus. Theor. Appl. Genet. 91, 1214-1221. [Online]. doi: 10.1007/BF00220932

Hamelin, R.C.; Hunt, R.S.; Geils, B.W.; Jensen, G.D.; Jacobi, V.; Lecours, N., 2000: Barrier to gene flow between eastern and western populations of Cronartium ribicola in North America. Phytopathology 90, 1073-1078. [Online]. doi: 10.1094/PHYTO.2000.90.10.1073

Hammond-Kosack, K.E.; Jones, J.D.G., 1997: Plant disease resistance genes. Annual Review of Plant Physiology and Plant Molecular Biology 48, 575-607. [Online]. doi: 10.1146/annurev. arplant.48.1.575

Harkins, D.M.; Johnson, G.N.; Skaggs, P.A.; Mix, A.D.; Dupper, G.E.; Devey, M.E.; Kinloch, B.B., JR; NeAle, D.B., 1998: Saturation mapping of a major gene for resistance to white pine blister rust in sugar pine. Theor. Appl. Genet. 97, 1355-1360. [Online]. doi: 10.1007/s001220051029

Hartl, D.L.; Clark, A.G., 1997: Principles of population genetics. Sunderland, MA: Sinauer Associates. 542 p.

Hijmans, R.J.; Cameron, S.E.; Parra, J.L.; Jones, P.G.; Jarvis, A., 2005: Very high resolution interpolated climate surfaces for global land areas. Int. J. Climatol. 25, 1965-1978. [Online]. doi: 10.1002/joc. 1276

HunT, R.S., 2004a: Environmental and inoculum-source effects on resistance of Idaho $\mathrm{F}_{2}$ western white pine in British Columbia. Canadian Journal of Plant Pathology 26, 351-357. [Online]. Available: http://pubs.nrccnrc.gc.ca/tcjpp/k04-039.html

Hunt, R.S., 2005: Effect of plant age and length of growing season on the development of blister rust cankers in western white pine. Canadian Journal of Plant Pathology 27, 453-457. [Online]. Available: http://pubs.nrccnrc.gc.ca/tcjpp/k05-051.html

Jermstad, K.D.; Bassoni, D.L.; Jech, K.S.; Ritchie, G.A.; Wheeler, N.C.; Neale, D.B., 2003 Mapping of quantitative trait loci controlling adaptive traits in coastal Douglas fir. III. Quantitative trait loci-by-environment interactions. Genetics 165, 1489-1506. [Online]. Available: http:// www.genetics.org/cgi/content/full/165/3/1489 [8/22/2006]

Jermstad, K.D.; Sheppard, L.A.; Kinloch, B.B., Jr; Delfino-Mix, A.; Ersoz, E.S.; Krutovsky, K.V.; NEALE, D.B., 2006: Isolation of a full-length CC-NBS-LRR resistance gene analog candidate from sugar pine showing low nucleotide diversity. Tree Genetics and Genomes 1. [Online]. doi: 10.1007/s11295-005-0029-6

Jerome, C.A.; Ford, B.A., 2002: The discovery of three genetic races of dwarf mistletoe Arceuthobium americanum provides insight into the evolution of parasitic angiosperms. Mol. Ecol. 11, 387-405. [Online]. doi: 10.1046/j.0962-1083.2002.01463.x.

Joly, D.L.; Langor, D.W.; Hamelin, R.C., 2006: Molecular and morphological evidence for interspecific hybridization between Cronartium ribicola and C. comandrae on Pinus flexilis in southwestern Alberta. Plant Dis. 90, 1552. [Online]. doi: 10.1094/PD-90-1552A

Kim, M.-S.; BRunsfeld, S.J., 2000: Rust resistance gene homolog isolated from western white pine (Pinus monticola Dougl.). In: Northwest Scientific Association, 2000 Annual meeting, Moscow, ID, 2000 March 16-19. 9 p.

Kim, M.-S.; Brunsfeld, S.J.; McDonald, G.I.; Klopfenstein, N.B., 2003: Effects of white pine blister rust (Cronartium ribicola) and rust-resistance breeding on genetic variation in western white pine (Pinus monticola). Theor. Appl. Genet. 106, 1004-1010. [Online]. doi: 10.1007/s00122-0021141-8

Kim, M.-S.; Klopfenstein, N.B.; Hamelin, R.C., 2005: Application of molecular genetic tools to studies of forest pathosystems. In: Forest Pathology from Genes to Landscapes. Ed. By Lundquist, J.E.; Hamelin, R.C. St. Paul, MN: American Phytopathology Society Press. pp. 9-19.

Kim, M.-S.; Klopfenstein, N.B.; Ota, Y.; Lee, S.K.; Woo, K.-S.; KaneKo, S., 2010: White pine blister rust in Korea, Japan, and other Asian regions: Comparisons and implications for North America. For. Pathol. 40, 382-401.

King, J.N.; David, A.; Noshad, D.; Smith, J., 2010: A review of genetic approaches to the management of blister rust in white pines. For. Pathol. 40, 292-313.

Kinloch, B.B., JR; Byler, J.W., 1981: Relative effectiveness and stability of different resistance mechanisms to white pine blister rust in sugar pine. Phytopathology 71, 386-391. [Online]. doi: 10.1094/Phyto-71-386

Kinloch, B.B., JR; Comstock, M., 1981: Race of Cronartium ribicola virulent to major gene resistance in sugar pine. Plant Dis. 65, 604-605.

Kinloch, B.B., Jr; Westfall, R.D.; White, E.E.; Gitzendanner, M.A.; Dupper, G.E.; Foord, B.M.; Hodgkiss, P.D., 1998: Genetics of Cronartium ribicola. IV. Population structure in western North America. Can. J. Bot. 76, 91-98. [Online]. doi: 10.1139/cjb-76-1-91 
Krutovsky, K.V.; Troggio, M.; Brown, G.R.; Jermstad, K.D.; Neale, D.B., 2004: Comparative mapping in the Pinaceae. Genetics 168, 447-461. [Online]. doi: 10.1534/genetics.104.028381

Latta, R.G.; MitTon, J.B., 1997: A comparison of population differentiation across four classes of gene marker in limber pine (Pinus flexilis James). Genetics 146, 1153-1163. [Online]. Available: http://www.genetics.org/cgi/content/abstract/146/3/1153

LatтA, R.G.; MitTon, J.B., 1999: Historical separation and present gene flow through a zone of secondary contact in ponderosa pine. Evolution 53, 769-776. [Online]. Available: http://www.jstor.org/stable/2640717

Ledig, F.T., 1988: The conservation of diversity in forest trees: Why and how should genes be conserved? Bioscience 38, 471-479. [Online]. Available: http://www.jstor.org/stable/1310951

Lippert, D.; Chowrira, S.; Ralph, S.G.; Zhuang, J.; Aeschliman, D.; Ritland, C.; Ritland, K.; Bohlmann, J., 2007: Conifer defense against insects: proteome analysis of Sitka spruce (Picea sitchensis) bark induced by mechanical wounding or feeding by white. Proteomics 7, 248-270. [Online]. doi: 10.1002/pmic.200600525

Liston, A.; Robinson, W.A.; Piñero, D.; Alvarez-Buylla, E.R., 1999: Phylogenetics of Pinus (Pinaceae) based on nuclear ribosomal DNA internal transcribed spacer region sequences. Mol. Phylogenet. Evol. 11, 95-109. [Online]. doi: 10.1006/mpev.1998.0550

Liu, J.-J.; Ekramoddoullah, A.K.M., 2003a: Root specific expression of a western white pine PR-10 gene mediated by different promoter regions in transgenic tobacco. Plant Mol. Biol. 52, 103-120. [Online] doi: 10.1023/A:1023930326839

Liu, J.-J.; Ekramoddoullah, A.K.M., 2003b: Isolation, genetic variation and expression of TIRNBS-LRR resistance gene analogs from western white pine (Pinus monticola Dougl. ex. D. Don.). Mol. Gen. Genomics. 270, 432-441. [Online]. doi: 10.1007/s00438-003-0940-1

Liu, J.-J.; Ekramoddoullah, A.K.M., 2006: The family 10 of plant pathogenesis-related proteins: their structure, regulation, and function in response to biotic and abiotic stresses. Physiol. Mol. Plant Pathol. 68, 3-13. [Online]. doi: 10.1016/j.pmpp.2006.06.004

Liu, J.-J.; Ekramoddoullah, A.K.M., 2007: The CC-NBS-LRR subfamily in western white pine (Pinus monticola D. Don.): targeted identification, gene expression and genetic linkage with disease resistance against Cronartium ribicola. Phytopathology 97, 728-736. [Online]. doi: 10.1094/ PHYTO-97-6-0728

Liu, J.-J.; Ekramoddoullah, A.K.M., 2008: Development of leucine-rich repeat polymorphism, amplified fragment length polymorphism, and sequence characterized amplified region markers to the Cronartium ribicola resistance gene $\mathrm{Cr} 2$ in western white pine (Pinus monticola). Tree Genetics and Genomes 4, 601-610. [Online]. doi: 10.1007/s11295-0080135-3

Liu, J.-J.; Hunt, R.S.; Ekramoddoullah, A.K.M., 2004: Recent insights into western white pine genetic resistance to white pine blister rust. Recent Research in Development, Biotechnology, and Bioengineering 6, 65-76.

Liu, J.-J.; Ekramoddoullah, A.K.M.; Piggott, N.; Zamani, A., 2005a: A pathogen/woundinducible PR10 promoter from Pinus monticola: molecular cloning and characterization in transgenic Arabidopsis plants. Planta 221, 159-169. [Online]. doi: 10.1007/s00425-004-1428-x

Liu, J.-J.; Ekramoddoullah, A.K.M.; Zamani, A., 2005b: A class IV chitinase is up-regulated by fungal infection and abiotic stresses and associated with slow-canker-growth resistance to Cronartium ribicola in western white pine (Pinus monticola). Phytopathology 95, 284-291. [Online]. doi: 10.1094/PHYTO-95-0284

Lodish, H.; Berk, A.; Kaiser, C.A.; Krieger, M.; Scott, M.P.; Bretscher, A.; Ploegh, H.; Matsudaira, P., 2004: Molecular Cell Biology. New York: W. H. Freeman.

Mackay, T.F.C., 2001: The genetic architecture of quantitative traits. Annu. Rev. Genet. 35, 303-339. [Online]. doi: 10.1146/annurev.genet.35.102401.090633

Maier, W.; Begerow, D.; Weiß, M.; Oberwinkler, F., 2003: Phylogeny of the rust fungi: an approach using nuclear large subunit ribosomal DNA sequences. Can. J. Bot. 81, 12-23. [Online]. doi: 10.1139/B02-113

McDonald, G.I.; Richardson, B.A.; Zambino, P.J.; Klopfenstein, N.B.; Kim, M.-S., 2006: Pedicularis and Castilleja are natural hosts of Cronartium ribicola in North America: a first report. Forest Pathology 36, 73-82. [Online]. doi: 10.1111/j.1439-0329.2006.00432.x

Meyers, B.C.; Dickerman, A.W.; Michelmore, R.W.; Sivaramakrishnan, S.; Sobral, B.W.; Young, N.D., 1999: Plant disease resistance genes encode members of an ancient and diverse protein family within the nucleotide-binding superfamily. Plant J. 20, 317-332. [Online]. doi: 10.1046/j.1365-313X.1999.t01-1-00606.x 
Meyers, B.C.; Morgante, M.; Michelmore, R.W., 2002: TIR-X and TIR-NBS proteins: Two new families related to disease resistance TIR-NBS-LRR proteins encoded in Arabidopsis and other plant genomes. Plant J. 32, 77-92. [Online]. doi: 10.1046/j.1365-313X.2002.01404.x

Michelmore, R.W.; Meyers, B.C., 1998: Clusters of resistance genes in plants evolve by divergent selection and a birth-and-death process. Genome Res. 8, 1113-1130. [Online]. doi: 10.1101/ gr.8.11.1113

Mitton, J.B.; Kreiser, B.R.; Latta, R.G., 2000: Glacial refugia of limber pine (Pinus flexilis James) inferred from the population structure of mitochondrial DNA. Mol. Ecol. 9, 91-97. [Online]. doi: 10.1046/j.1365294x.2000.00840.x

Morse, A.M.; Nelson, C.D.; Covert, S.F.; Holliday, A.G.; Smith, K.E.; Davis, J.M., 2004: Pine genes regulated by the necrotrophic pathogen Fusarium circinatum. Theor. Appl. Genet. 109, 922932. [Online]. doi: 10.1007/s00122-004-1719-4

Neale, D.B.; Ingvarsson, P.K, 2008: Population, quantitative and comparative genomics of adaptation in forest trees. Curr. Opin. Plant Biol. 11, 149-155. [Online]. doi: 10.1016/j.pbi. 2007.12.004

Neale, D.B.; Savolainen, O., 2004: Association genetics of complex traits in conifers. Trends Plant Sci. 9, 325-330. [Online]. doi: 10.1016/j.tplants.2004.05.006

Newcombe, G.; Stirling, B.; McDonald, S.; Bradshaw, H.D., 2000: Melampsora x columbiana, a natural hybrid of $M$. medusae and M. occidentalis. Mycol. Res. 104, 261-274. [Online]. doi: 10.1017/S0953756299001665

Patton, R.F., 1961: The effect of age upon susceptibility of eastern white pine to infection by Cronartium ribicola. Phytopathology 51, 429-434.

Price, R.A.; Liston, A.; Strauss, S.H., 1998: Phylogeny and systematics of Pinus. In: Ecology and Biogeography of Pinus. Ed. By Richardson, D.M. Cambridge, UK: Cambridge University Press. pp. 49-68.

Rajora, O.P.; Dancik, B.P., 2000: Population genetic variation, structure, and evolution in Engelmann spruce, white spruce, and their natural hybrid complex in Alberta. Can. J. Bot. 78, 768-780. [Online]. doi: 10.1139/cjb-78-6-768

Rajora, O.P.; Rahman, M.H.; Buchert, G.P.; Dancik, B.P., 2000: Microsatellite DNA analysis of genetic effects of harvesting in old-growth eastern white pine (Pinus strobus) in Ontario, Canada. Mol. Ecol. 9, 339-348. [Online]. doi: 10.1046/j.1365-294x.2000.00886.x

Ralph, S.; Oddy, C.; Cooper, D.; Yueh, H.; Jancsik, S.; Kolosova, N.; Philippe, R.N.; Aeschliman, D.; White, R.; Huber, D.; Ritland, C.E.; Benoit, F.; Rigby, T.; Nantel, A.; Butterfield, Y.S.N.; Kirkpatrick, R.; Chun, E.; Jiu, J.; et al., 2006: Genomics of hybrid poplar (Populus trichocarpa $\mathrm{x}$ deltoides) interacting with forest tent caterpillars (Malacosoma disstria). Mol. Ecol. 15, 1275-197. [Online]. doi: 10.1111/j.1365-294X.2006.02824.x

ReE, R.H., 2005: Phylogeny and the evolution of floral diversity in Pedicularis (Orobanchaceae). International Journal of Plant Science 166, 595-613. [Online]. doi: 10.1086/430191

Rehfeldt, G.E., 2006: A spline model of climate for the western United States. Gen. Tech. Rep. RMRS-GTR-165. Fort Collins, CO: U.S. Department of Agriculture, Forest Service, Rocky Mountain Research Station. 21p. [Online]. Available: http://www.treesearch.fs.fed.us/pubs/21485

Rehfeldt, G.E.; Hoff, R.J.; Steinhoff, R.J., 1984: Geographic patterns of genetic variation in Pinus monticola. Bot. Gaz. 145, 229-239. [Online]. Available: http://www.jstor.org/stable/2474344

Rehfeldt, G.E.; Wykoff, W.R.; Ying, C.C., 2001: Physiologic plasticity, evolution, and impacts of a changing climate on Pinus contorta. Climatic Change 50, 355-376. [Online]. doi: 10.1023/A:1010614216256

Richardson, B.A.; Brunsfeld, S.J.; Klopfenstein, N.B., 2002a: DNA from bird-dispersed seed and wind-disseminated pollen provides insights into postglacial colonization and population genetic structure of whitebark pine (Pinus albicaulis). Mol. Ecol. 11, 215-227. [Online]. doi: 10.1046/ j.1365-294X.2002.01435.x

Richardson, B.A.; Klopfenstein, N.B.; Brunsfeld, S.J., 2002b: Assessing Clark's nutcracker seedcaching flights using maternally inherited mitochondrial DNA of whitebark pine. Canadian Journal of Forest Research 32, 1103-1107. [Online]. doi: 10.1139/x02-037

Richardson, B.A.; Klopfenstein, N.B.; Peever, T.L., 2005: Assessing forest-pathogen interactions at the population level. In: Forest Pathology from Genes to Landscapes. Ed. By Lundquist, J.E.; Hamelin, R.C. St. Paul, MN: American Phytopathology Society Press. pp. 21-30.

Richardson, B.A.; Zambino, P.J.; Klopfenstein, N.B.; McDonald, G.I.; Carris, L.M., 2007: Assessing host specialization among aecial and telial hosts of the white pine blister rust fungus, Cronartium ribicola. Can. J. Bot. 85, 299-306. [Online]. doi: 10.1139/B07-031 
Richardson, B.A.; Klopfenstein, N.B.; Zambino, P.J.; McDonald, G.I.; Geils, B.W.; Carris, L.M., 2008: Influence of host resistance on the genetic structure of the white pine blister rust fungus in the western United States. Phytopathology 98, 413-420. [Online]. doi: 10.1094/PHYTO-98-40413

Richardson, B.A.; Kim, M.-S.; Klopfenstein, N.B.; Ota, Y.; Woo, K.S.; Hamelin, R.C., 2009: Tracking the footsteps of an invasive plant-pathogen: intercontinental phylogeographic structure of the white-pine-blister-rust fungus, Cronartium ribicola. In: Breeding and Genetic Resources of Five-Needle Pines Conference, Yangyang, Republic of Korea, 2008 September 22-26. Ed. By Noshad, D.; Noh, E.; King, J.; SNiezko, R. Yangyang: Korea Forest Research Institute. pp. $56-62$.

Schultheis, L.M.; Donoghue, M.J., 2004: Molecular phylogeny and biogeography of Ribes (Grossulariaceae) with an emphasis on gooseberries (subg. Grossularia). Syst. Bot. 29, 77-96. [Online]. doi: 10.1600/036364404772974239

Schürch, S.; Linde, C.C.; Knogge, W.; Jackson, L.F.; McDonald, B.A., 2004: Molecular population genetic analysis differentiates two virulence mechanisms of the fungal avirulence gene NIP1. Mol. Plant Microbe Interact. 17, 1114-1125. [Online]. doi: 10.1094/MPMI.2004.17.10.1114

Scotti-Saintagne, C.; Mariette, S.; Porth, I.; Goicoechea, P.G.; Barreneche, T.; Bodenes, C.; Burg, K.; Kremer, A., 2004: Genome scanning for interspecific differentiation between two closely related oak species [Quercus robur L. and Q. petraea (Matt.) Lie] Genetics 168, 1615-1626. [Online]. doi: 10.1534/genetics.104.026849

Senters, A.E.; Soltis, D.E., 2003: Phylogenetic relationships in Ribes (Grossulariaceae) inferred from ITS sequence data. Taxon 52, 51-66. [Online]. Available: http://www.jstor.org/stable/3647301

St Clair, J.B.; Mandel, N.L.; Vance-Borland, K.W., 2005: Genecology of Douglas fir in western Oregon and Washington. Annals of Botany 96, 1199-1214. [Online]. doi: 10.1093/aob/mci278

Syring, J.; Willyard, A.; Cronn, R.; Liston, A., 2005: Evolutionary relationships among Pinus (Pinaceae) subsections inferred from multiple low-copy nuclear loci. Am. J. Bot. 92, 2086-2100.

Syring, J.; Farrell, K.; Businsky, R.; Cronn, R.; Liston, A., 2007: Widespread genealogical nonmonophyly in species of Pinus subgenus Strobus. Syst. Biol. 56, 163-181. [Online]. doi: 10.1080/10635150701258787

Томваск, D.F., 2001: Clark's Nutcracker: agent of regeneration. In: Whitebark pine communities: Ecology and restoration. Ed. By Tомваск, D.F.; Arno, S.F.; Keane, R.E. Washington, DC: Island Press. pp. 89-104.

Tомваск, D.F; Achuff, P., 2010: Blister rust and western forest biodiversity: Ecology, values, and outlook for white pines. For. Pathol. 40, 186-225.

Van der Vossen, E.A.; van der Voort, J.N.; Kanyuka, K.; Bendahmane, A.; Sandbrink, H.; Baulcombe, D.C.; Bakker, J.; Stiekema, W.J.; Klein-Lankhorst, R.M., 2000: Homologues of a single resistance-gene cluster in potato confer resistance to distinct pathogens: a virus and a nematode. Plant J. 23, 567-576. [Online]. doi: 10.1046/j.1365-313x.2000.00814.x

Vasemägi, A.; Primmer, C.R., 2005: Challenges for identifying functionally important genetic variation: The promise of combining complementary research strategies. Mol. Ecol. 14. 3623-3642. [Online]. doi: 10.1111/j.1365294X.2005.02690.x

Vogler, D.R.; Bruns, T.D., 1998: Phylogenetic relationships among the pine stem rust fungi (Cronartium and Peridermium spp.). Mycologia 90, 244-257. [Online]. Available: http:// www.jstor.org/stable/3761300

WAGNER, D.B., 1992: Nuclear, chloroplast, and mitochondrial DNA polymorphisms as biochemical markers in population genetic analyses of forest trees. New Forest. 6, 373-390. [Online]. doi: 10.1007/BF00120653

Wakamiya, I.; Newton, R.J.; Johnston, J.P.; Price, H.J., 1993: Genome size and environmental factors in the genus Pinus. Am. J. Bot. 80, 1235-1241. [Online]. Available: http://www.jstor.org/ stable/2445706

Wang, X.-R.; Tsumura, Y.; Yoshimaru, H.; Nagasaka, K.; Szmidt, A.E., 1999: Phylogenetic relationships of Eurasian pines (Pinus, Pinaceae) based on chloroplast rbcL, matK, rpl20-rps18 spacer, and trnV intron sequences. Am. J. Bot. 86, 1742-1753. [Online]. doi: http://www.jstor.org/ stable/2656672

WAng, X.-Q.; TANK, D.C.; SAnG, T., 2000: Phylogeny and divergence times in Pinaceae: Evidence from three genomes. Mol. Biol. Evol. 17, 773-781. [Online]. Available: http://mbe.oxfordjournals. org/cgi/content/full/17/5/773

Warren, J.M.; Covert, S.F., 2004: Differential expression of pine and Cronartium quercuum f. sp. fusiforme genes in fusiform rust galls. Appl. Environ. Microbiol. 70, 441-451. [Online]. doi: 10.1128/AEM.70.1.441-451.2004 
Whitehead, A.; Crawford, D.L., 2006: Variation with and among species in gene expression: raw material for evolution. Mol. Ecol. 15, 1197-1211. [Online]. doi: 10.1111/j.1365-294X.2006.02868.x

Willyard, A.; Syring, J.; Gernandt, D.S.; Liston, A.; Cronn, R., 2007: Fossil calibration of molecular divergence infers a moderate mutation rate and recent radiations for Pinus. Mol. Biol. Evol. 24, 90-101. [Online]. doi: 10.1093/molbev/msl131

Wu, H.X.; YinG, C.C.; MuIR, J.A., 1996: Effect of geographic variation and jack pine introgression on disease and insect resistance in lodgepole pine. Canadian Journal of Forest Research 26, 711-726. [Online]. doi: 10.1139/x26081

Xiao, S.; Elllwood, S.; Calis, O.; Patrick, E.; Li, T.; Coleman, M.; Turner, J.G., 2001: Broadspectrum mildew resistance in Arabidopsis thaliana mediated by RPW8. Science 291, 118-120. [Online]. doi: 10.1126/science.291.5501.118

Yanchuк, A.D., 2001: A quantitative framework for breeding and conservation of forest tree genetic resources in British Columbia. Canadian Journal of Forest Research 31, 566-576. [Online]. doi: $10.1139 / \mathrm{cjfr}-31-4-566$

Yu, X.; Ekramoddoullah, A.K.M.; TAylor, D.W.; PiggotT, N., 2002: Cloning and characterization of a cDNA of cro rI from the white pine blister rust fungus Cronartium ribicola. Fungal Genetics and Biology 35, 53-66. [Online]. doi: 10.1006/fgbi.2001.1308

Zambino, P.J., 2010: Biology and pathology of ribes and their implications for management of white pine blister rust. For. Pathol. 40, 264-291.

Zhang, X.Y.; Lu, Q.; Sniezko, R.A.; Song, R. Q.; Man, G., 2010: Blister rusts in China: Hosts, pathogens, and management. For. Pathol. 40, 369-381.

(c) 2010 Her Majesty the Queen in right of Canada, Natural Resources Canada, Canadian Forest Service as originally published in Nature. 